\title{
The origin of the Old English dialects
}

\section{Frederik Kortlandt}

1. It has been argued that the Old English dialects either reflect old tribal divisions or developed after the Anglo-Saxon emigration. I think that neither view is correct. In the following I intend to show that the early divergences between West Saxon and Kentish on the one hand and Anglian (Mercian and Northumbrian) on the other are the result of a chronological difference between two waves of migration from the same dialectal area in northern Germany.

2. Hans Nielsen (1981: 251 -252) lists thirteen pre-invasion correspondences between Anglian and continental Germanic languages and four correspondences of Kentish and West Saxon. I shall briefly review the material.

2.1. The usual nom. acc. pl. ending of the $\bar{o}$-stems is $-a$ in West Saxon and Kentish and - $e$ in Anglian. Since Kern (1906) has shown that the former represents the original nominative and the latter the original accusative ending, they can be derived from ProtoGermanic *-ōs and ${ }^{*}-\bar{o} n s$, respectively. Though it is usually assumed that the nasal was lost in the latter ending (e. g. Hollifield 1980: 43), there is no evidence for this view (cf. in this connection Beekes 1982: 55). There is no reason to postulate tonal distinctions for Proto-Germanic. As I have indicated elsewhere (1983: 172), I assume the following developments of Proto-Germanic final syllables:

$\begin{array}{llllll}\text { PGmc. } & \text { Goth. } & \text { ON } & \text { OE } & \text { OS } & \text { OHG } \\ *_{-}-\bar{o} & -a & \text { zero } & -(u) & -(u) & -(u) \\ *_{-} \bar{o} n & -a & \text { zero } & -e & -a & -a \\ \text { *}_{-} \bar{o} n s & -\bar{o} s & -a r & -e & -a & -\bar{a} \\ \text { *}_{-} \bar{o} s & -\bar{o} s & -a r & -a & -o & -o \\ \text { *}_{-} \bar{o} t & -\bar{o} & -a & -a & -o & -o \\ { }^{*}-\bar{o} a(n) & -\bar{o} & -a & -a & -o & -o\end{array}$

Apart from the compensatory lengthening in Old High German, Proto-Germanic ${ }^{*_{-}} \bar{o} n s$ merged with ${ }^{*_{-}} \bar{o} s$ in the north and the east, and with $*_{-} \bar{o} n$ in the west. This divergence must evidently be connected with the different chronology of the rise of nasal vowels on the one hand and the loss of $*_{-s}$ on the other. The acc. sg. ending 
of the $\bar{o}$-stems (PGmc. ${ }^{*}-\bar{o} n$ ) replaced the gen. sg. ending (PGmc. $*_{-} \bar{o} s$ ) in West Germanic in order to remove the homophony with the gen. pl. ending (PGmc. ${ }^{*}-\bar{o} a n$, cf. Kortlandt 1978: 293). For the same reason the acc. pl. ending (PGmc. ${ }^{*}-\bar{o} n s$ ) replaced the nom. pl. ending (PGmc. *-oss), but this development did not reach the Kentish and West Saxon dialects, which had apparently left the continent by this time, and did not affect the pronominal flexion, where the homophony never arose. Conversely, the nom. pl. ending replaced the acc. pl. ending in West Saxon and Kentish in order to remove the homophony with the acc. sg. ending. The latter development has nothing to do with the merger of nom. pl. ${ }^{*} \bar{o} s$ and acc. pl. *-ons in Old Norse and Gothic, which resulted from the phonetic loss of the nasal.

2.2. The nom. pl. form Mercian oexen, Northumbrian exen, Old Frisian ixen, West Norse $y x n$, øxn preserves the zero grade of the proto-form *uksnes 'oxen', which was lost elsewhere.

2.3. Mercian and Northumbrian share with Old Norse the preservation of the zero grade gen. sg. ending -ur, -or in the word for 'father'. This ending was original in the words for 'mother' and 'brother', from where it spread to the word for 'father' in North and West Germanic. Unlike the other languages, Old English preserves the difference between acc. sg. fader on the one hand, and módor and brōpor on the other.

2.4. The Kentish hapax lexresta can be identified with Old Frisian lerest 'least'. This unique correspondence between Kentish and a continental language is insignificant.

2.5. Kentish and West Saxon share with Old Frisian and Old Saxon the use of the dative for the accusative of the 1st and 2nd sg. personal pronouns. This is apparently a common North Sea Germanic innovation which can be dated to the period before the migrations. On the other hand, the dialect from which Old High German evolved differentiated the accusative from the dative of the 1 st and 2 nd $\mathrm{pl}$. personal pronouns by the addition of ${ }^{*}-i k$. The latter innovation spread to the Anglian dialects of Old English, leaving traces in Old Saxon and Old Low Franconian, but not in West Saxon or Kentish, which had apparently left the continent at the time already. The long accusative forms are evidently stylistically marked in Old English and disappear after the oldest records.

2.6. The Northumbrian 1st pl. possessive pronoun $\bar{u} s a$, which has been preserved in modern dialects between York and Stafford (cf. Orton et al. 1978, map M75), corresponds to Old Saxon üsa, 
Old Frisian üse, and Old Low Franconian unsa, representing an innovation in comparison with Gothic unsar, Old High German unserēr, Old Franconian unsere, and the usual Old English forms $\bar{u}$ ser, $\bar{u}$ re. The innovation can evidently be dated to the period of the last migrations. It did not affect the $2 \mathrm{nd} \mathrm{pl}$. form éower, Old High German iuwerèr, Old Franconian iuweer, cf. Old Saxon iuwa, Old Frisian iuwe, Old Low Franconian iuuwa.

2.7. The Northumbrian acc. sg. form of the masc. demonstrative pronoun pene beside pone can be identified with Old Frisian thene, Old Saxon thena beside thana, Middle Dutch dien beside Old Low Franconian thana, Old High German den. The introduction of $e$-vocalism in the acc. sg. form evidently spread from the southern dialects to the north and reached the pre-English dialects at the time of the last migrations. It also affected the interrogative pronoun in Old High German (hwenan, wen) and Old Saxon (hwena), but not in Old English (hwone).

2.8. Anglian has preserved the reduplicated preterits heht 'called', leolc 'played', leort 'let', reord 'advised', cf. Gothic haihait, lailaik, lailōt, rairōp.

2.9. The $r$-forms in the present tense of the verb 'to be' are more widespread in Anglian than in West Saxon and Kentish. The - $r-$ probably spread from the 1 st $\mathrm{pl}$. form *erum, ON erom, OHG birum, to 2 nd $\mathrm{pl}$. ON erop, OHG birut, and subsequently to $3 \mathrm{rd} \mathrm{pl}$. $\mathrm{ON}$ ero, $\mathrm{OE}$ (e)aron, $-u n$, and $2 \mathrm{nd} \mathrm{sg}$. OE eart, (e) arp. It was eventually generalized in Scandinavian. The West Saxon 2nd sg. form eart must have originated before the substitution of $3 \mathrm{rd} \mathrm{pl}$. $\operatorname{sind}($ on) for the 1 st and 2 nd pl. forms. Since the latter development was a shared innovation of Old English, Old Frisian, and Old Saxon, it must be dated to the period before the migrations. The Anglian plural form (e)aron must therefore be regarded as an archaism representing an earlier common innovation.

2.10. West Saxon preserves the original coexistence of 1st sg. eom and $b \bar{e} o$ 'am'. The latter form adopted the $-m$ of the former in Anglian bèom, biom, Old Saxon bium. This was apparently a shared innovation dating from the time between the early and the later migrations. Conversely, the former paradigm adopted the $b$ - of the latter in Old High German bim, bist, birum, birut, Old Frisian bim, Middle Dutch bem.

2.11. The rare Northumbrian 2nd sg. form of the verb 'to be' is can hardly be identified with Gothic is. It is probably the $3 \mathrm{rd} \mathrm{sg}$. form used for the $2 \mathrm{nd} \mathrm{sg}$. 
2.12. The Anglian plural form dedon beside dydon 'did' can be compared with Old Frisian deden, Old Saxon dedun or dādun, Old High German tātun, Gothic -dédun. It represents an archaism in comparison with $\mathrm{OE}$ dydon.

2.13. Reflexes of *waljan in the paradigm of the verb 'will' are frequent in Old High German, but occur also in Old Saxon, Old Frisian, and Anglian. In the preterit, the stem is limited to Anglian walde and Old Saxon walda. It is evidently an innovation which reached pre-English from the south at the time of the later migrations.

2.14. The reflex of Proto-Indo-European $*_{\bar{e}}$ is $\bar{e}$ in Anglian, Kentish, Old Frisian, and Gothic, $\bar{x}$ in West Saxon, and $\bar{a}$ in Old High German, Old Saxon, and Old Norse. There are also instances of $\bar{e}$ in Old Saxon, e. g., bèrun, lēsun. Van Wijk (1911) has established that the original reflex of PIE ${ }^{*} \bar{e}$ is $\bar{x}$ in West Flanders, Zealand, South Holland, Utrecht, and the southern part of North Holland, whereas it is $\bar{e}$ in the remainder of North Holland and in Old Frisian. The reflex $\bar{a}$ invaded the Low Franconian area from the south, while the entire coast from Flanders to Ostfriesland preserved the fronted reflex until the eleventh century (cf. Gysseling 1962: $7-8$ ). There can be little doubt that Dutch and West Saxon $\vec{x}$ is an archaism. The retraction of this vowel to $\bar{a}$ in Old High German, Old Saxon, and Old Norse must be viewed in connection with the rise of $\bar{e}_{2}$, and its raising to $\bar{e}$ in Anglian, Kentish, Old Frisian, and Gothic with the monophthongization of ai. The twofold reflex in Old Saxon is matched by a twofold reflex of $a i$ in the same area. We can therefore date the raising of $\bar{x}$ to $\bar{e}$ in Anglian, Kentish, and Old Frisian to the period of the migrations.

3. A reconsideration of the correspondences between the Old English dialects and the continental Germanic languages shows that the early divergences between Anglian and West Saxon can be explained from a chronological difference between two stages of a single continental dialect. In comparison with Anglian, West Saxon has preserved two structural archaisms: the nom. pl. ending of the $\bar{o}-$ stems $-a$, and the reflex $\bar{\alpha}$ of PIE $* \bar{e}$. On the other hand, Anglian has preserved five accidental irregularities: the umlauted nom. pl. form of 'oxen', the zero grade gen. sg. ending of 'father', the reduplicated preterits, and the plural forms (e) aron 'are' and dedon 'did'. Three of these retentions are also found in Old Norse, one in Gothic, and one in Old Saxon and Old High German. Besides, 
Anglian differs from West Saxon as a result of seven innovations shared with continental West Germanic languages: the substitution of the acc. pl. ending of the $\bar{o}$-stems $-e$ for the nom. pl. ending, the creation of a distinct accusative of the 1 st and $2 \mathrm{nd}$ pl. personal pronouns, the creation of the $1 \mathrm{st}$ pl. possessive pronoun $\bar{u} s a$, the introduction of $e$-vocalism in the acc. $\mathrm{sg}$. form of the masc. demonstrative pronoun, the creation of 1st sg. bëom 'am', the spread of *waljan to the paradigm of the verb 'will', and the raising of $\bar{x}$ to $\bar{e}$. These developments, all of which have at least left traces in Old Saxon, can be dated to the period after the early migrations.

4. According to the explanation put forward here, we must distinguish between an earlier, 'Saxon', and a later, 'Anglian' migration. One may wonder if there is any historical evidence for this view.

Nielsen states that the Saxons lived in present-day Holstein according to Ptolemy (2nd century) and 'appear to have been in control of the whole region between the Elbe and the Weser from the middle of the third century' (Nielsen 1981: 265). They reached the Netherlands in the fourth century. The Angles can hardly be separated from the present-day district of Angeln in eastern Schleswig. I would suggest that 'Anglian' refers to the original Saxons of Angeln, more or less as the French word allemand refers to the original Germans of Alemannia. As Nielsen (1981: 271) points out, Bede does not always observe the distinction between Angles and Saxons, and the eventual preference for the term 'Anglian' is probably due to its distinctiveness from the continental Saxons.

The traditional designation for the Germanic invaders in Celtic sources is 'Saxons'. This name was evidently established at the first stage of the invasion, which can be identified with the period from the time of Vortigern (around 450) until the battle of Mount Badon (about 500, cf. Jackson 1953: 199). There followed almost half a century of peace, the 'Saxons' having settled in Kent and Sussex. The territory of Essex and Middlesex was largely uninhabited at that time. In the north, 'the great gateway by which the Angles penetrated into the north Midlands and Yorkshire was the estuary of the Humber' (Jackson 1953: 207). Though in the Yorkshire Wolds and at York itself 'archaeological finds seem to indicate a more or less unbroken continuity of occupation between the late Roman and pagan Saxon periods' (Jackson 1953: 212), there is no historical evidence for a kingdom of Deira before the second half of the sixth century. During the latter period Deira must have gained 
considerable strength in view of the spectacular expansion after the battle of Catterick about 600 which is described in the Gododdin. It seems that the battle of Catterick can be viewed as the northern equivalent of the battle of Mount Badon, except for the fact that it was won by the other side. Thus, I suggest that the 'Saxon' invasion yielded the conquest of Kent and Sussex in the fifth century, whereas the 'Anglian' invasion can be connected with the subjugation of the north which started around the middle of the sixth century. There is no linguistic evidence for a different continental homeland, especially because the shared innovations of Anglian and Old Saxon point to geographical contiguity after the early migrations.

\section{References}

Beekes, Robert S. P.

1982 "GAv. må, the PIE. word for "moon, month", and the perfect participle', Journal of Indo-European Studies 10: 53-64.

Gysseling, M.

1962 'Het oudste Fries', It Beaken 24: 1-26.

Hollifield, Patrick H.

1980 'The phonological development of final syllables in Germanic', Die Sprache 26: 19-53; 145-178.

Jackson, Kenneth

1953 Language and history in early Britain (Edinburgh: University Press).

Kern, J. H.

1906 'Zum nom. und acc. plur. der $\bar{a}$-stämme im ags.', Beiträge zur Geschichte der deutschen Sprache und Literatur 31: 272-276.

Kortlandt, Frederik

1978 'On the history of the genitive plural in Slavic, Baltic, Germanic, and Indo-European', Lingua 45: 281-300.

1983 'On final syllables in Slavic', Journal of Indo-European Studies 11: $167-185$.

Nielsen, Hans F.

1981 Old English and the continental Germanic languages (Innsbruck: Institut für Sprachwissenschaft).

Orton, Harold - Stewart Sanderson - John Widdowson (eds)

1978 The linguistic atlas of England (London: Croom Helm).

Wijk, Nicolaas van

1911 'Een Oudwestnederfrankies $\bar{x}$-dialekt', Tijdschrift voor Nederlandsche taal-en letterkunde 30: 161-189. 